\title{
Erratum: Heritable GATA2 mutations associated with familial AML-MDS: a case report and review of literature
}

Juehua Gao ${ }^{1 *}$, Ryan D. Gentzler ${ }^{2}$, Andrew E. Timms ${ }^{3,4}$, Marshall S. Horwitz ${ }^{3}$, Olga Frankfurt ${ }^{2}$, Jessica K. Altman² and LoAnn C. Peterson ${ }^{1}$

After the publication of this work [1], it was brought to our attention that the correct annotation at the protein level for one of the two reported GATA2 mutations is T358N (p.Thr358Asn), but not T358K (p. Thr358Lys), as the forward and reverse sequencing in Fig. $2 \mathrm{~b}$ were swapped leading to the previous incorrect annotation.

\footnotetext{
Author details

'Department of Pathology, Northwestern University Feinberg School of Medicine, Feinberg 7-209A, 251 E. Huron Street, Chicago, IL 60611, USA. ${ }^{2}$ Division of Hematology and Oncology, Department of Internal Medicine, Northwestern University Feinberg School of Medicine, 251 E. Huron Street, Chicago, IL 60611, USA. ${ }^{3}$ Department of Pathology, University of Washington, Seattle, WA 98195, USA. ${ }^{4}$ Present address: Seattle Children's Research Institute, Seattle, WA 98101, USA.
}

Received: 1 August 2014 Accepted: 21 December 2015

Published online: 29 December 2015

\section{Reference}

1. Gao J, Gentzler RD, Timms AE, Horwitz MS, Frankfurt O, Altman JK, et al. Heritable GATA2 mutations associated with familial AML-MDS: a case report and review of literature. J Hematol Oncol. 2014;7(1):36.

\footnotetext{
* Correspondence: j-gao@northwestern.edu

Submit your next manuscript to BioMed Central and we will help you at every step:

- We accept pre-submission inquiries

- Our selector tool helps you to find the most relevant journal

- We provide round the clock customer support

- Convenient online submission

- Thorough peer review

- Inclusion in PubMed and all major indexing services

- Maximum visibility for your research

Submit your manuscript at www.biomedcentral.com/submit 